\title{
Leaping for leptin: the 2010 Albert Lasker Basic Medical Research Award goes to Douglas Coleman and Jeffrey M. Friedman
}

\begin{abstract}
D Lasker Foundation announced that they will award Coleman and Friedman (Figure 1) with the 2010 Albert Lasker Basic Medical Research Award in recognition of their contributions toward the discovery of leptin, a hormone that regulates appetite and body weight. This hormone provides a key means by which changes in nutritional state are sensed and in turn modulate the function of many other physiologic processes. The story of the discovery of the first molecular target of obesity is one of tenacity and determination.
\end{abstract} ouglas Coleman never intended to study diabetes or obesity. Jeffrey M. Friedman had childhood dreams of being a veterinarian. But together, the two scientists have opened the field of obesity research to molecular exploration. On September 21, the Albert and Mary

\section{From Canada to Maine}

Douglas Coleman was raised in Ontario, Canada, the only child of English immigrant parents, who encouraged him to excel in school; he recalled, "Although my parents never had the luxury of completing high school, they always encouraged me to pursue a higher education, and in high school, I developed a keen interest in chemistry and biology." Coleman pursued his interest in chemistry at McMaster University. It was there he met his future wife, Beverly Benallick, "the only girl to graduate in Chemistry in the Class of 1954." During his time at McMaster University, Coleman began to focus on organic chemistry and had the fortune of working with, "a very dynamic professor, Sam Kirkwood, who not only taught me the rudiments of biochemistry, but also instilled an appreciation of the scientific method." Kirkwood encouraged Coleman to continue his biochemistry studies at the University of Wisconsin, at which he received a PhD in 1958.

In those days, postdoctoral fellowships were rare, and graduates had two options: academia or industry. Coleman took a third option, as an associate staff scientist at what was then known as the Roscoe B. Jackson Memorial Laboratory in Bar Harbor, Maine. Coleman has noted,
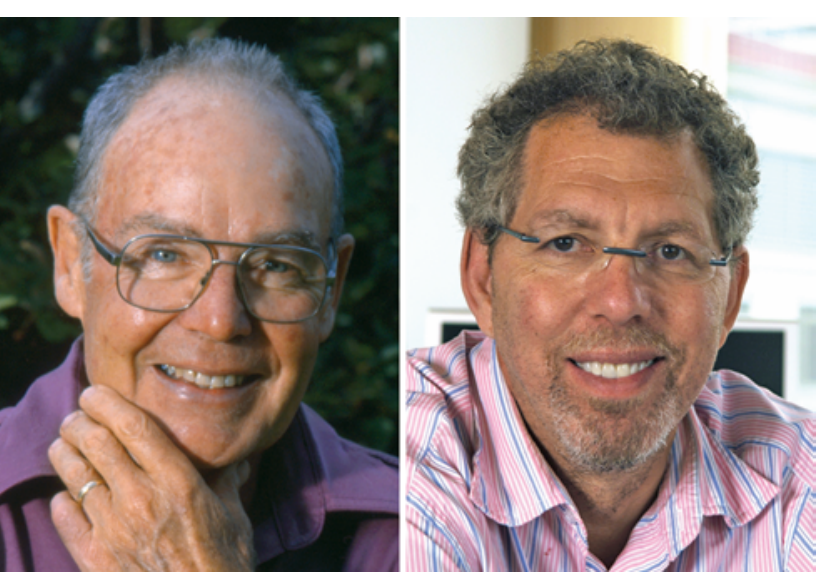

Figure 1

Douglas Coleman (left) and Jeffrey M. Friedman (right) share the covery of leptin, a breakthrough that opened obesity research to molecular exploration.

\section{Making magic from a mutant}

His early work involved muscular dystrophy and the development of a new field, mammalian biochemical genetics, establishing that genes control enzyme turnover as well as structure. However, his focus changed when a colleague asked for his help characterizing a mutant (Figure 3) that had spontaneously arisen at the labs. He recalled, "Initially, I had no intention of studying the diabetes/obesity syndrome, but in 1965, a spontaneous mouse mutation was discovered, and I began research that would consume much of my scientific thought for the better part of three decades." The new mutant was polydipsic and polyuric as well as being massively obese and hyperphagic. His colleague, Katherine Hummel, was studying diabetes insipidus and asked if he could determine whether the new mutant had diabetes insipidus or mellitus. He reported back that it was diabetes mellitus: "Her initial response was that she was not interested, but I convinced her that with a little

"My intention was to stay one or two years, expanding my skills in multiple fields, especially genetics and immunology. To my great pleasure, The Jackson Laboratory provided a rich environment, including world-class animal models of disease, interactive colleagues, and a backyard that included the stunning beauty of Acadia National Park." The Coleman family put down roots, raising their three sons there as Coleman rose through the ranks to senior staff scientist and served terms as assistant director of research and interim director (Figure 2). He noted, "Without a doubt, I was lucky in my choice of starting my career at The Jackson Laboratory. It was a wonderful place in which to work, and I never pursued another position.” further work we could produce a solid manuscript announcing this potentially valuable mutant to the world." This mouse owed its phenotype to two defective copies of a gene that researchers dubbed diabetes $(d b)(1)$.

When Coleman and his colleagues began characterizing the $d b / d b$ mouse, they began to ponder whether some circulating factor might regulate the severity of diabetes: perhaps a factor in the normal mouse could inhibit the development of the obesity and diabetes found in the $d b / d b$ mutant. Conversely, perhaps a circulating factor present in the $d b / d b$ mouse might cause the diabetes-like syndrome in the normal mouse. If the hypothetical factor was carried through the blood, Coleman reasoned, they could test for its presence 


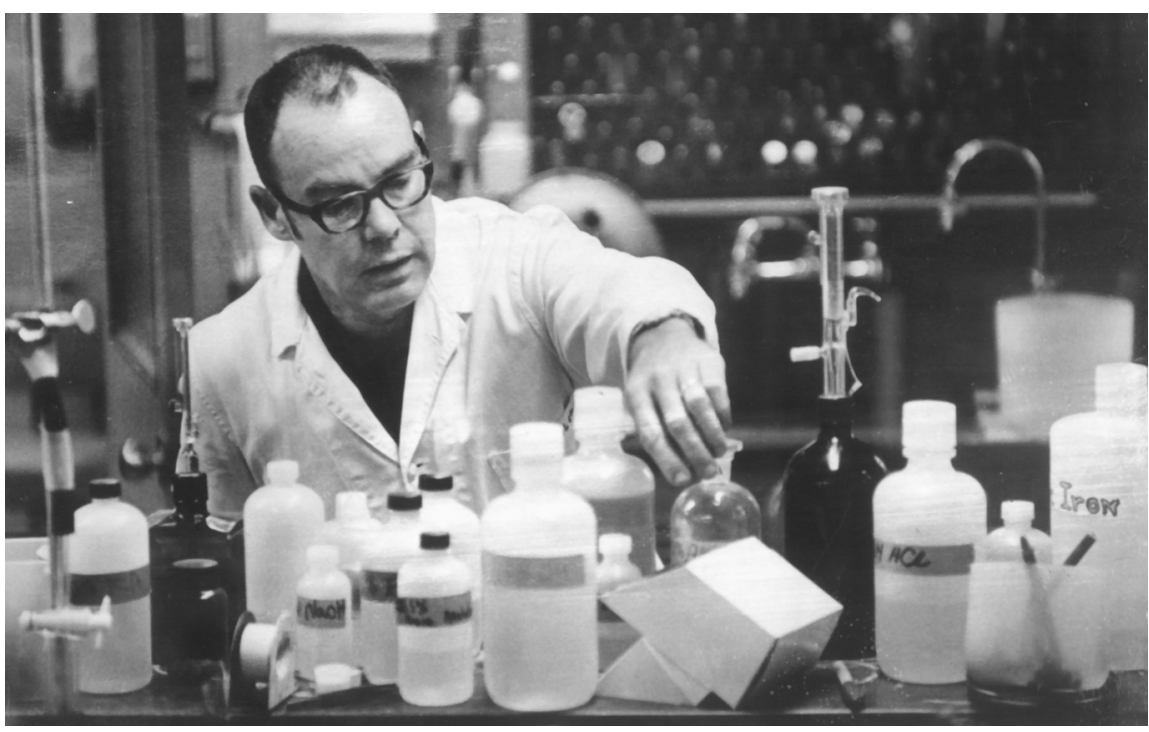

Figure 2

Coleman at the bench at The Jackson Laboratory in 1960. Photo courtesy of The Jackson Laboratory.

by linking the blood supplies of the various mouse strains - an experimental setup called parabiosis. Fortunately, others at The Jackson Laboratory were using parabiosis to assess whether any circulating factors were involved in anemic mutants, and they were able to show Coleman how to do it successfully.

When Coleman hooked the wild-type mice and the $d b / d b$ mice together, rather than overeating, as the $d b / d b$ mice did, the wild-type mice stopped eating and died from starvation (Figure 4 and ref. 2). His hypothesis was correct: the $d b / d b$ mice indeed must have released a factor that inhibited the wild-type animals' drive to eat, but the mutant animals could not respond to it.

Coleman needed more proof of this mystery circulating factor regulating food intake. He turned to another overweight mouse that also had arisen by chance at The Jackson Laboratory, this one called "obese," whose aberrant physiology arises from two defective copies of a different gene (ob) (3). Unfortunately, the $o b / o b$ mouse was on a different genetic background, and due to immune-mediated rejection, parabiosis could only be performed successfully on mice with the same strain background. Coleman described his need for resolve, "Since the obese and diabetic mutants were on different genetic backgrounds, it took years for me to be able to perform all of the desired pairings."
Coleman persevered and finally got the strains to match so he could successfully hook them together in a parabiosis experiment. When joined to a $d b / d b$ mouse, the $o b / o b$ mouse stopped eating and starved to death, while the $d b / d b$ mouse remained obese, just as the normal mice had in the previous experiment. In contrast, attaching wild-type mice to $o b / o b$ animals did nothing to the wild-type mice and caused the $o b / o b$ mice to limit their food consumption and gain less weight (Figure 4). Coleman concluded that the $o b / o b$ mice failed to produce a hormone that inhibits eating, while the $d b / d b$ mice overproduced it but lack the receptor to transmit the hormonal signal (4).

Coleman faced some skepticism for his conclusion that obesity was not just about willpower and eating habits but also involved chemical and genetic factors. In this regard, he said, "When I published these findings, the long-standing dogma was that obesity was a behavioral problem (a lack of willpower) and not a physiological problem (a hormonal imbalance). I had to deal with this behavioral dogma most of my career."

To validate his hypothesis, Coleman would need to identify the $d b$ and $o b$ genes and protein products, a task that proved to be an insurmountable challenge at the time. He noted, "Definitive proof of my conclusions required isolating the satiety factor - a feat that resisted rigorous experimentation." That is, until Jeffrey Friedman set his sights upon the task.

\section{An accidental research scientist}

Friedman was born in Orlando, Florida but spent the bulk of his youth in Long Island in New York: "My father was a doctor, but the world of my parents' parents was essentially the world of immigrants - from the Pale [of Settlement]. And in that world, you did whatever you could to get your feet on the ground. And in my family, the highest form of achievement was being a doctor." Friedman set on the path to become a doctor, but there were bumps on the road. He recalls opening seven college rejection letters on the same day but did manage to gain acceptance at a six-year program at Rensselaer Polytechnic Institute and Albany Medical College of Union University in upstate New York that allowed him to finish with his $\mathrm{MD}$ at age 22 .

After his third year of internal medicine residency at Albany Medical Center Hospital, he had no concrete plans for the following year, as he was not scheduled to begin a fellowship at the Brigham and Women's Hospital in Boston until a year later. Friedman recalled, "I had no particular plans for the gap year, and John Balint, one of my professors, thought I might like research - why he thought I might have some particular aptitude, I can't really tell. He said, 'I have this friend

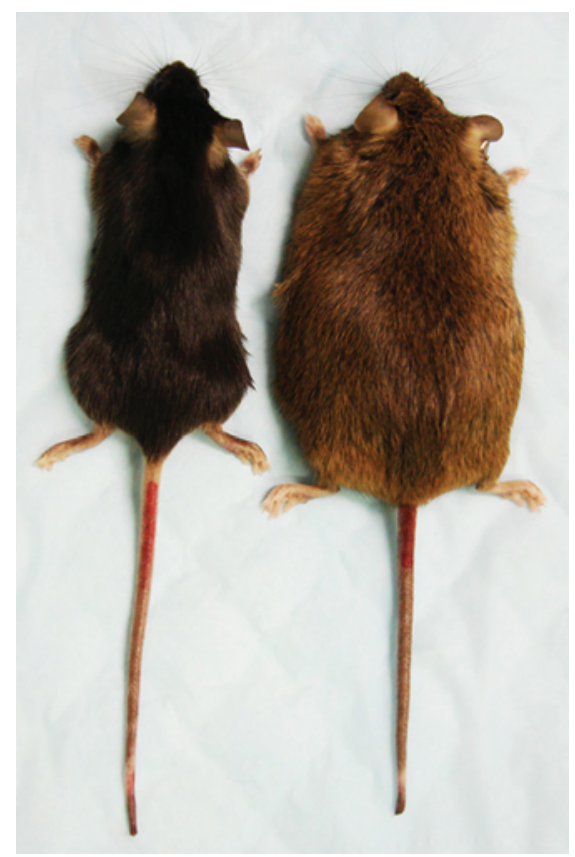

\section{Figure 3}

Wild-type and obese mice. Photo courtesy of Rexford Ahima. 


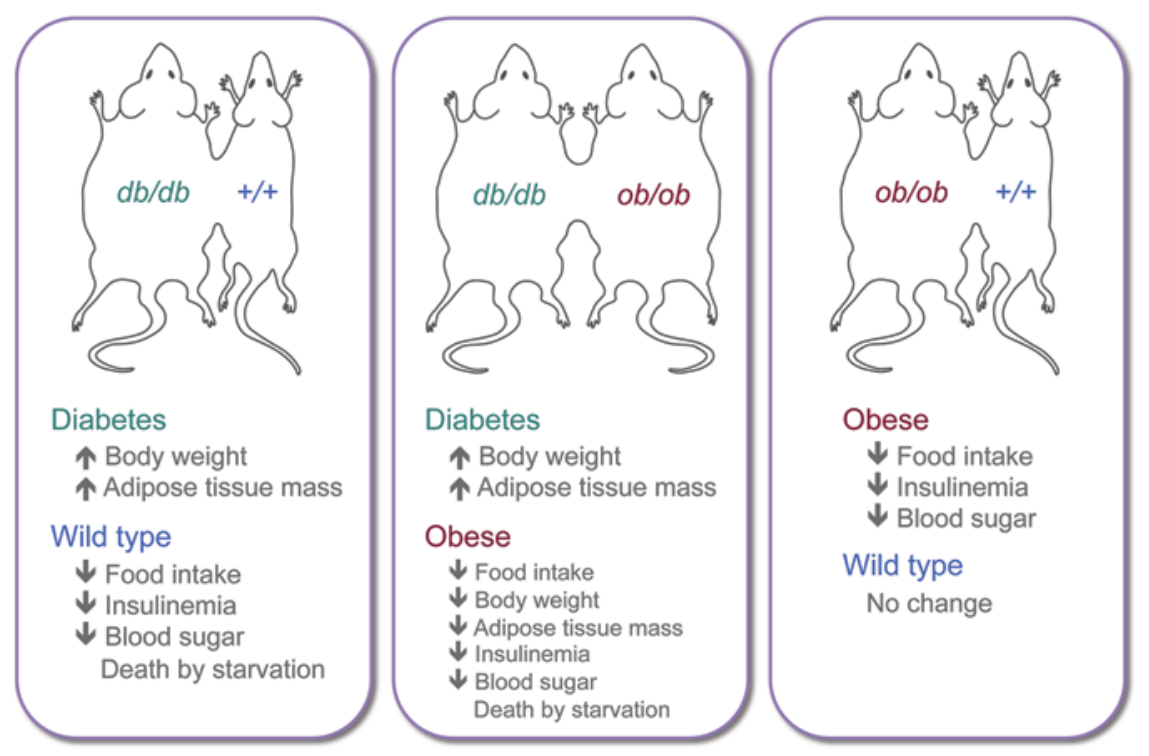

Figure 4

Summary of parabiosis experiments performed by Coleman. Slide courtesy of The Jackson Laboratory.

at Rockefeller [Mary Jeanne Kreek], why don't you go spend a year with her and see if you like research?' I didn't know what else I was going to do. My mother thought I should go spend the year as a ship's doctor."

\section{A fat chance}

Friedman was enraptured by what Kreek studied: how molecules control behavior. "That was 1981 and it was beginning to be evident that molecular biology was going to have a big impact, so instead of going to the Brigham for a fellowship, I abandoned medicine and decided to get a PhD with Jim Darnell [2002 Lasker award winner for his work in RNA processing and cytokine signaling], who was one of the leaders in molecular biology," he noted. Friedman's thesis was on the regulation of liver gene expression - how genes are turned on and off as liver regenerates. However, there was something he did on the side that was more impactful: Kreek had asked him to work with Bruce Schneider, another faculty member at Rockefeller University, to make an RIA for $\beta$-endorphin. However, Schneider's primary interest was not in $\beta$-endorphin, but rather in cholecystokinin (CCK). In 1979, Rosalyn Yalow had published a paper in which she reported reduced levels of CCK in the brain of $o b / o b$ mice and boldly claimed that CCK was the circulating factor that caused the $o b / o b$ mice to be fat (5). Friedman recalled, "Well, Bruce had the exact opposite data, this was published in the JCI (6), and this started a battle with Yalow over who was correct. To address this, in 1982 Don Powell, Bruce, and I set out to clone the Cck gene so we could map it. We collaborated with Peter D'Eustachio at NYU, who showed that it was on chromosome 9 (7); $o b$ is on $6, d b$ is on 4. I still have Peter's notebook entry from that time in which he wrote, 'CCK does not map to chromosome 6 , home of $o b$.'” So the question for Friedman became, if the circulating hormone is not CCK, then what is? When he started his own laboratory in 1986 at Rockefeller, he set out to find it, and as he recalls, "In a way what the $o b$ mouse represented to me was another instance where a molecule was controlling a behavior, the same as in Mary Jeanne's lab.”

\section{Do these genes make me look fat?}

In the mid ' 80 s, positional cloning was not easy, but Friedman turned to the then-new techniques of physical gene mapping, complimented by conventional genetic mapping in mice. It had long been known that the $o b$ gene resided somewhere on mouse chromosome 6 , but narrowing down the region was arduous, as the trait is recessive, necessitating the breeding of several generations. Friedman and his laboratory first determined which DNA markers were inherited along with the obese phenotype in over 1,600 mice crossbred from obese and nonobese strains. He remembers, "It was a mind numbing exercise you hoped someday would lead somewhere." Since the genetic and physical maps are colinear, DNA markers that were linked to $o b$ in genetic crosses could be used to clone the surrounding DNA. Using this approach, they eventually identified the portion of the genome in which all markers were always coinherited with $o b$ among the progeny of the crosses. This region defined the chromosomal region in which the $o b$ gene resided. As they had predicted when the crosses were set up, this region corresponded to an approximately 300,000-base pair region on chromosome 6 . They then screened recombinant clones across this region for exon-intron boundaries, which indicate the presence of genes. One of the first three genes they isolated was expressed exclusively in adipose tissue, and the expression of the mutant gene was found to be 20 times greater in one of the $o b / o b$ mutants than in controls. In a second mutant, the gene was not expressed at all, providing clear evidence that this gene encoded the $o b$ gene. When they looked in the human genome, they found an $o b$ homolog that was $84 \%$ identical with the mouse $o b$ gene, establishing $o b$ as a highly conserved, biologically important gene (8).

Once a fat-specific gene was found in the vicinity of $o b$, he remembered being almost numb with excitement as a set of confirmatory experiments unfolded. "I went in late on a Saturday night, and I found a radioactive probe for this gene, and I found a blot with RNA from fat tissue of normal and mutant mice. I hybridized the blot that evening and washed it at 1 in the morning. I couldn't sleep, and I woke up at 5 or 6 and developed the blot. When I looked at the data, I immediately knew that we had cloned $o b$. When I saw it, I was in the darkroom, and I pulled up the film and looked at it under the light and got weak-kneed. I sort of fell backwards against the wall. This gene was in the right region of the chromosome, it was fat specific, and its expression was altered in two independent strains of $o b$ mice. Before this, we didn't know where $o b$ would be expressed - and while fat was one of the tissues I considered, in principle the gene could have been expressed in any specialized cell type anywhere that had no obvious relationship to fat. But on the other hand, seeing a gene in the right region expressed exclusively in the fat ... that gets 

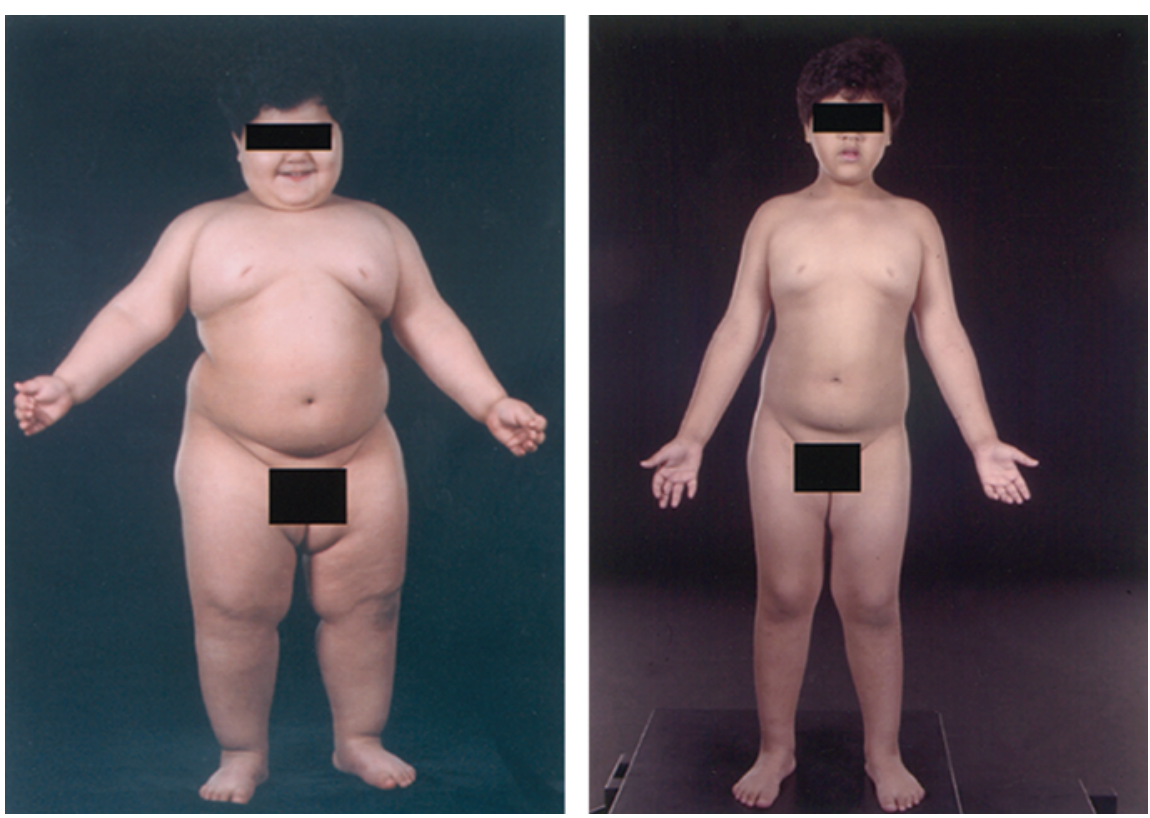

Figure 5

Effects of r-metHuLeptin on the weight a child with congenital leptin deficiency. Clinical photographs are of the child before (height $=107 \mathrm{~cm}$ ) and 24 months after $r$-metHuLeptin therapy (height $=124 \mathrm{~cm}$ ). Figure reprinted from ref. 16 .

your attention." When he found out at 6 in the morning, he called his wife and said "we did it!," and then, a few hours later he, called his former $\mathrm{PhD}$ advisor Jim Darnell: "I told him but I wasn't sure he believed me." That afternoon, he met some friends at Pete's Tavern, "and we opened a bottle of champagne, and I told them, 'I think this is going to be pretty big."”

Next Friedman set his sights on actually identifying the product secreted by the $o b$ gene and validating Coleman's circulating hormone hypothesis. Together with Stephen Burley, his laboratory engineered E. coli to fabricate the secreted protein, generated antibodies that would bind it, and showed that humans and rodents secrete it. In the last sentence of the 1995 Science paper describing these findings, Friedman "propose[d] that this $16-\mathrm{KD}$ protein be called leptin, derived from the Greek root leptos, meaning thin" (9). The paper also showed that $d b / d b$ mice made excess quantities of leptin, as predicted by Coleman, and its levels in plasma decreased in normal animals and obese humans after weight loss. He remembered, "It was an unbelievable time in the lab. The idea that there was this hormone that regulated body weight, and that we had found it, was just unimaginable. I'd wake up in the middle of the night just smiling."
As for the name leptin, it has not only a Greek root, but a French one too. At a meeting, Friedman met Frenchman Roger Guillemin, who won a Nobel Prize for his work on peptide hormone production by the brain. A few weeks after the meeting, Friedman got a letter from him that he recalls saying, "I really liked what you had to say, but I have one quibble: you refer to these as obesity genes, but I think they are lean genes because the normal allele keeps you thin. But calling them lean genes sounds awkward. The nicest sounding root for thin is from Greek, so I propose you call $o b$ and $d b$ 'lepto-genes." So when it came time to name it, Friedman remembered Guillemin's suggestion, and therein, the name leptin was coined.

\section{Leptin's legacy}

Later in 1995, another group described the leptin receptor (10), and then subsequently, Friedman and another group showed that this leptin receptor is encoded by the $d b$ gene and has multiple forms, one of which is defective in Coleman's originally described $d b / d b$ mice $(11,12)$. Friedman also showed that the leptin receptor is especially abundant in the hypothalamus in which leptin can activate signal transduction and phosphorylation of the Stat3 transcription factor (13).
Over the years, numerous laboratories have studied leptin's mechanism of action. Leptin acts on receptors expressed in groups of neurons in the hypothalamus, in which it inhibits appetite, in part, by counteracting the effects of neuropeptide $\mathrm{Y}$, a potent feeding stimulant secreted by cells in the gut and in the hypothalamus, by thwarting the effects of anandamide, another potent feeding stimulant, and by promoting the synthesis of $\alpha$-MSH (melanocyte stimulating hormone), an appetite suppressant (14). Leptin is produced in large amounts by white adipose tissue but can also be produced in lesser amounts by brown adipose tissue, syncytiotrophoblasts, ovaries, skeletal muscle, stomach, mammary epithelial cells, bone marrow, pituitary, and liver. Leptin's actions are also not limited to regulating food intake, as it is has been shown to have roles in fertility, immunity, angiogenesis, and surfactant production. Friedman adds that the hormone, "has effects on many physiological systems, including the immune system where it modulates $\mathrm{T}$ cells, macrophages, and platelets. It now appears that leptin provides a key means by which nutritional state can regulate a host of other physiological systems." While most of these actions are mediated by effects on the CNS, two of many key questions are, which of leptin's effects on peripheral systems are direct, and which are indirect via the brain?

\section{A magic bullet?}

The first proof that leptin was important in humans came in 1997 when Stephen O'Rahilly and colleagues found two morbidly obese children who carried a mutation in the leptin gene (15). These researchers went on to show that leptinreplacement therapy could be useful in individuals with leptin mutations (16). Injection of leptin into these children led to rapid weight loss and markedly reduced food intake (Figure 5). Leptinreplacement therapy also has potent effects in other clinical settings, including lipodystrophy, a disease state in which animals and humans have little white fat and develop severe diabetes, with profound insulin resistance and high plasma lipid levels. Because this syndrome is associated with low circulating levels of leptin, Shimomura and colleagues tested the effects of leptin-replacement therapy in mice and showed that it was highly effec- 


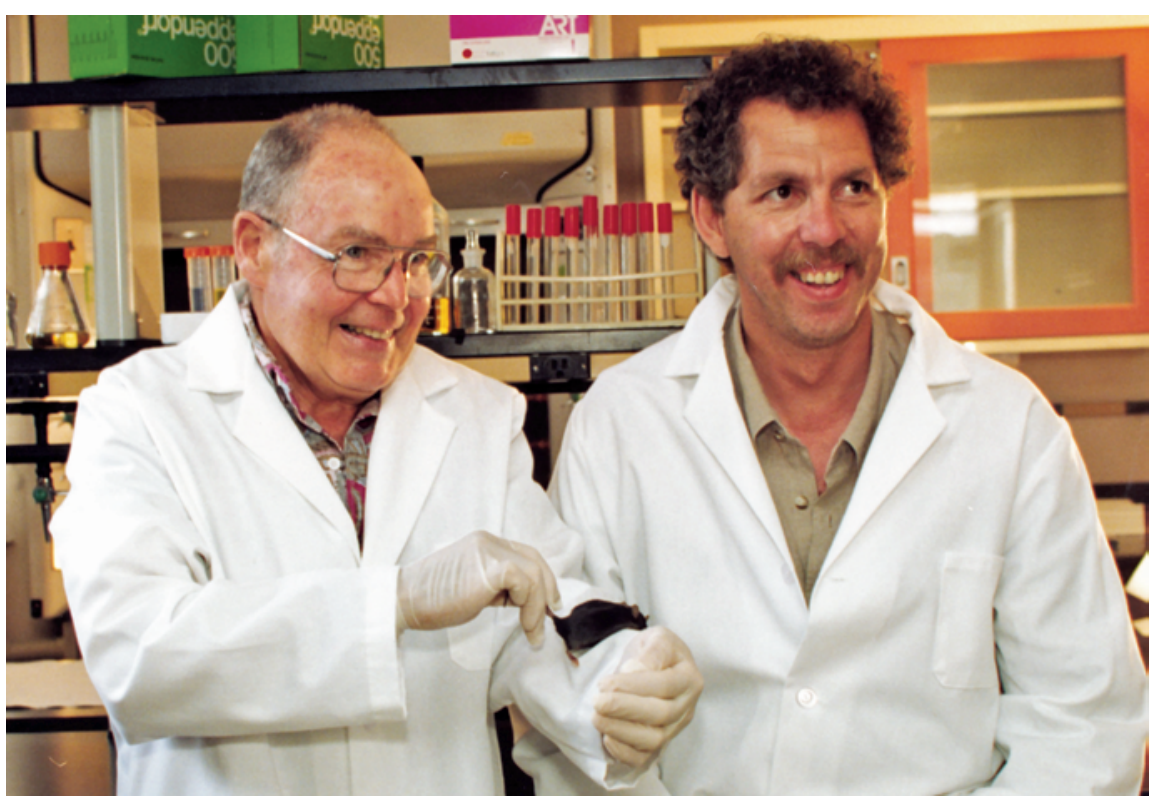

Figure 6

Coleman and Friedman, together at The Jackson Laboratory, in 1995. Coleman has noted that he was gritting his teeth in the photo as "the mouse was biting my arm like crazy!" Photo courtesy of The Jackson Laboratory.

tive (17); similar efficacy was later shown in humans (18). More recently, leptin treatment has shown a profound anti-diabetic effect in type 1 diabetic animals (19). Leptin replacement has also been shown to be of clinical benefit in other states of leptin deficiency, including hypothalamic amenorrhea (20).

Excited by leptin's potential for the treatment of obesity, the biotech company Amgen paid \$20 million to Rockefeller to license the hormone. With so much of the world's population overweight or obese, a treatment or cure would be a major advance in public health and would likely be very lucrative. Amgen sponsored a large clinical trial, giving leptin to overweight adults, but while a subset of obese patients lost significant amounts of weight on leptin, the average magnitude of the effect was minimal, dampening hopes that leptin was the magic bullet in the obesity fight (21). After the trial, Amgen announced that they had suspended studies of the effects of leptin for the treatment of human obesity.

Friedman says he understands why the trials failed: "Even before leptin was tested in obese patients, we knew from animal studies that this hormone was not likely to be a panacea for every obese patient and that the response seen in $o b / o b$ mice wasn't going to be the typical case for obese humans. Leptin levels are elevated in obese humans, suggesting that obesity is often associated with leptin resistance and raising the possibility that increasing already high levels was going to be of arguable benefit." The key to making leptin work may be in coaxing the brain to respond to leptin: some people are simply not sensitive enough or they develop resistance. Friedman predicts that through personalized medicine, doctors may at some point be able to identify which obese people will respond to leptin. In the meantime, there is some clinical evidence that leptin's ability to reduce weight among obese patients can be restored by combining it with other agents (22).

\section{The thrill of discovery}

For all the social implications, potential profits, and medical possibilities, Friedman is circumspect but proud about the discovery of leptin, saying, "whether it finds its way into general usage as an antiobesity drug, the use of modern methods to identify and target the components of the leptin- signaling pathway will, I believe, form the basis for new pharmacological approaches to the treatment of obesity and other nutritional disorders." Coleman agrees, stating that "with the discovery of leptin and the subsequent cloning of the leptin receptor, the field exploded. With these findings, two long-standing misconceptions were definitively laid to rest: obesity was not merely a behavioral problem but rather had a significant physiological component; and adipose tissue was not merely a fat-storage site but rather an important endocrine organ."

Both Coleman and Friedman (Figure 6) were overwhelmed and humbled by the news that they would receive the 2010 Lasker Award for Basic Medical Research. Coleman notes, "I have always viewed this award as one of the most esteemed of the several truly prestigious biomedical research awards, and it is with great pride and humility that I accept this prestigious prize. I was also especially delighted to learn that I would be sharing this award with Jeffrey Friedman, who always acknowledged my earlier contributions to our field." Friedman added, "It is an honor to join a group of other winners who really are at the highest level of science. To be placed among them is just hard to fathom.”

Coleman retired from his scientific career in 1991. He has said that at his retirement ceremony "someone commented that my career was characterized by the ability to use the simplest technique to answer the most complex biological questions." Friedman, however, is still at the bench and active as ever in his hunt to determine exactly how leptin regulates food intake. Through their determination and persistence, the two have provided a molecular framework for understanding obesity, but they have different opinions about how much luck played into their findings. Coleman has noted that he favors the Louis Pasteur quote, "Luck favors the prepared mind." But Friedman has a different perspective, stating "my story suggests that in many cases, the prepared mind is favored by chance."

\section{Ushma S. Neill}

\section{Acknowledgments}

As Coleman was away and unavailable for comment during the preparation of this article, his quotations were taken from an autobiography he wrote when accepting the Shaw prize in 2009, from his acceptance remarks for the Lasker prize, and from a profile written by Luther Young posted on the Bangor Daily News in 2009 (http://www.bangordailynews.com/story/ Hancock/Scientists-work-at-Jackson-Lablauded,118612?print=1). 
1. Hummel KP, Dickie MM, Coleman DL. Diabetes, a new mutation in the mouse. Science. 1966 ; 153(740):1127-1128.

2. Coleman DL, Hummel KP. Effects of parabiosis of normal with genetically diabetic mice. Am J Physiol. 1969;217(5):1298-1304.

3. Ingalls AM, Dickie MM, Snell GD. Obese, a new mutation in the house mouse. J Hered. 1950; 41(12):317-318.

4. Coleman DL. Effects of parabiosis of obese with diabetes and normal mice. Diabetologia. 1973; 9(4):294-298.

5. Straus E, Yalow RS. Gastrointestinal peptides in the brain. Fed Proc. 1979;38(9):2320-2324.

6. Schneider BS, Monahan JW, Hirsch J. Brain cholecystokinin and nutritional status in rats and mice. J Clin Invest. 1979;64(5):1348-1356

7. Friedman JM, Schneider BS, Barton DE, Francke U. Level of expression and chromosome mapping of the mouse cholecystokinin gene: implications for murine models of genetic obesity. Genomics. 1989; 5(3):463-469.

8. Zhang Y, Proenca R, Maffei M, Barone M, Leopold L, Friedman JM. Positional cloning of the mouse obese gene and its human homologue. Nature. 1994;372(6505):425-432.

9. Halaas JL, et al. Weight-reducing effects of the plasma protein encoded by the obese gene. Science. 1995;269(5223):543-546.

10. Tartaglia LA, et al. Identification and expression cloning of a leptin receptor, OB-R. Cell. 1995;83(7):1263-1271.

11. Chen $\mathrm{H}$, et al. Evidence that the diabetes gene encodes the leptin receptor: identification of a mutation in the leptin receptor gene in $\mathrm{db} / \mathrm{db}$ mice. Cell. 1996;84(3):491-495.

12. Lee $\mathrm{GH}$, et al. Abnormal splicing of the leptin receptor in diabetic mice. Nature. 1996;379(6566):632-635

13. Vaisse C, Halaas JL, Horvath CM, Darnell JE Jr, Stoffel M, Friedman JM. Leptin activation of Stat3 in the hypothalamus of wild-type and ob/ob mice but not db/db mice. Nat Genet. 1996;14(1):95-97.

14. Friedman JM, Halaas JL. Leptin and the regulation of body weight in mammals. Nature. 1998; 395(6704):763-770

15. Montague CT, et al. Congenital leptin deficiency is associated with severe early-onset obesity in humans. Nature. 1997;387(6636):903-908.
16. Farooqi IS, et al. Beneficial effects of leptin on obesity, T cell hyporesponsiveness, and neuroendocrine/ metabolic dysfunction of human congenital leptin deficiency. J Clin Invest. 2002;110(8):1093-1103.

17. Shimomura I, Hammer RE, Ikemoto S, Brown MS, Goldstein JL. Leptin reverses insulin resistance and diabetes mellitus in mice with congenital lipodystrophy. Nature. 1999;401(6748):73-76.

18. Oral EA, et al. Leptin-replacement therapy for lipodystrophy. NEngl J Med. 2002;346(8):570-578.

19. Wang MY, et al. Leptin therapy in insulin-deficient type I diabetes. Proc Natl Acad Sci U S A. 2010; 107(11):4813-4819.

20. Welt CK, et al. Recombinant human leptin in women with hypothalamic amenorrhea. $N$ Engl J Med. 2004;351(10):987-997.

21. Heymsfield SB, et al. Recombinant leptin for weight loss in obese and lean adults: a randomized, controlled, dose-escalation trial. JAMA. 1999; 282(16):1568-1575.

22. Roth JD, et al. Leptin responsiveness restored by amylin agonism in diet-induced obesity: evidence from nonclinical and clinical studies. Proc Natl Acad Sci U S A. 2008;105(20):7257-7262. 